\title{
AERO-STRUCTURAL OPTIMIZATION OF JOINED-WING AIRCRAFT
}

\author{
Milosz KaLinowsKi \\ Institute of Aviation, Aleja Krakowska 110/114, 02-256 Warsaw, Poland \\ milosz.kalinowski@ge.com
}

\begin{abstract}
Joined-wing aircraft due to its energy characteristics is a suitable configuration for electric aircraft when designed properly. However, because of the specific for this aircraft phenomenons (e.g. static indeterminacy of structure, aerodynamic interference of lifting surfaces) it demands more complicated methods to model its behavior than a traditional aircraft configurations. For these reasons the aero-structural optimization process is proposed for joined-wing aircrafts that is suitable for preliminary design. The process is a global search, modular algorithm based on automatic geometry generator, FEM solver and aerodynamic panel method. The range of aircraft was assumed as an objective function. The algorithm was successfully tested on UAV aircraft. The improvement of $19 \%$ of total aircraft range is achieved in comparison to baseline aircraft. Time of evaluation of this global search algorithm is similar to the time characteristic for local optimization methods. It allows to reduce the time and costs of preliminary design of joined-wing.
\end{abstract}

Keywords: Joined-wing, multidyscyplinary optimization, preliminary design.

\section{INTRODUCTION}

Joined-wing (Pic.1) is an unconventional proposal for the future commercial airplanes. This configuration was proposed for the first time by Prandtl in 1924 [1], but the first extensive research was performed by Wolkovitch in 1986 [2]. Joined-wing consists of two lifting surfaces that are similarly loaded and so it has no horizontal stabilizer. Usually, the forward lifting surface is located in front of the center of gravity while the second is behind it. Both surfaces can be connected together in many possible ways which provide different aircraft performance and strength features. Due to possible advantages it is developed under a number of UAV projects all over the world.

Researchers quickly realized that aircraft in this configuration has a possibility to achieve all its characteristic advantages and be better than the classic configuration only if the optimization is conducted on the very first development stages [3]. That is why the majority of publications related to this configuration refers to the optimization problem. The simplest optimizations that have been 


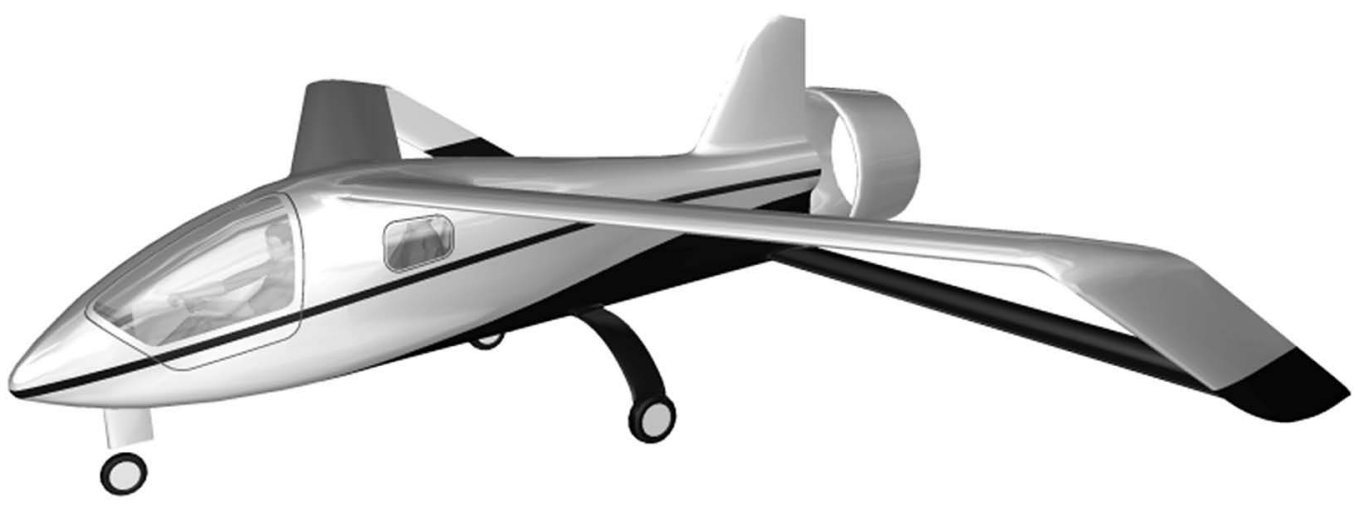

Pic. 1. Joined-wing aircraft [Kalinowski, 2016].

performed were concerned only with aerodynamics of lifting surfaces. An example of such paper is work of Gagnon [4] who conducted the optimization of the joined-wing by changing the skew angles, distributions of twist and length of wing chord and the position of mass center. On the other hand, pure structure optimization studies are sometimes considered [5,6] with minimum mass set as an objective. Researchers are mainly scoped on optimization of structure properties and topology under limited strength allowable values. It is worth paying attention to the work of Kim et al [7], which was scoped on the non-linear behavior of structure (large deformations were taken into account). In order to reduce computation cost of expensive non-linear analyses the authors confined them to minimum. This was possible by introducing the equivalent load method that simplifies the problem to linear structure analysis. That kind of approach allowed Kim to consider a non-linear structure in the optimization process.

Shortly afterwards, researchers began to carry out multidisciplinary optimization which is much more time consuming because it takes into account a number of disciplines at once, instead of considering them separately. In an effect the first attempts of multidisciplinary optimization are based on models of structure simplified to a spatial beams and aerodynamic panel codes [3]. Later, when the computational power of computers allowed to conduct more sophisticated analyzes, people began to use FE shell model of wings and programs based on the Navier-Stokes equations [8]. The noteworthy work is a work of Sivaji et al [9]. The authors conducted optimization taking into account modal analysis of joined-wing configuration. Additionally, they considered the fluid-structure interaction by introducing a simplified one-dimensional model of wings. Deflections of one-dimensional model loaded by aerodynamic loads, were transferred to the analysis of 3D model.

To carry out the most complicated optimization of the joined-wing aircraft it is worth using response surface method to achieve time savings effectively. Rasmussen [10] used this method in the proposed optimization algorithm with the objective of minimization wings structure weight. In his process, he took into account the long-term mission of the airplane and corresponding loads such as: aerodynamic loads, mass, and impact during taxiing. The general optimization algorithm was 
divided into two stages: generation of response surface points and searching for optimum. Generation of points was a multistage process. During calculations mass of the structure was changing, which requires updating of loads. The response surface was created by using masses corresponding to different values of design variables. A similar optimization concept was used to create the algorithm shown in this paper.

\section{AIRCRAFT MODEL}

The problem of multidisciplinary optimization of full configuration of the aircraft is a very complicated task, thus it cannot be carried out using only traditional analytic methods. Achieving correct results in respect of quality and quantity requires huge computation time. That is why, the only possible way to do this is to use computer and automatic algorithms. For this reason, before staring creation of optimization algorithm, it should be considered what specific conditions it needs to meet in order to work effectively. The major computational cost in such problems almost always lies in evaluation of the objective function. In the proposed algorithm it was decided to create models of physical phenomena that are adequate to possible changes for the considered configurations (global modeling of aircraft rather than local effects consideration). As a result, only the most important disciplines like aerodynamics, structure strength and flight mechanics are considered.

\subsection{Geometry Generator}

Optimization of global geometry of aircraft requires preparation of parametric geometric model. The created model has a fixed topology (the wings connected to the fuselage, the vertical stabilizer, the internal structure) but can change in some ways defined by the parameters. Applied parameters are dimensions of curves that create skeleton of geometry. They define how to create external surfaces of aircraft. Due to the fact that quality and robustness are demanded in an optimization, it was decided to use B-spline curves and surfaces in this process, which are commonly used in similar tasks $[11,12]$. B-spline surface is defined by the following equation:

$$
p(u, w)=\sum_{i=0}^{n} \sum_{j=0}^{m} \bar{P}_{i j} N_{i, p u}^{u}(u) N_{j, p w}^{w}(w)
$$

where: $\bar{P}_{i j}-$ control points, $N_{i, p u}^{u}, N_{j, p w}^{w}-$ B-spline basis functions.

The main advantages of this type of geometric formations is the ability to model very complex shapes without local oscillations known from approximation and interpolation based on polynomial functions. However, B-spline geometries are formulated by a very complex theory, thereby geometry creation may be slightly more time consuming than for simpler kinds of geometry.

To simplify the definition and the use of geometry in the next steps a few separately created surfaces were combined. They are cut to the intersection lines that are found automatically. 

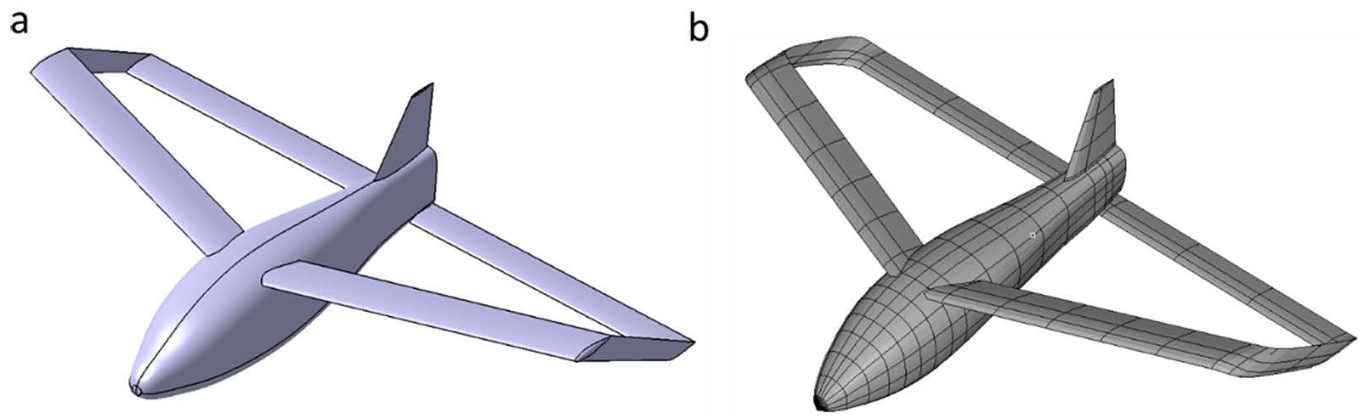

Pic. 2. Geometries generated with CATIA (a) and with proposed B-Spline surfaces module (b) [Kalinowski, 2016].

\subsection{Structural Strength}

Strength checks are performed based on the created FE model. It has to reflect a real behavior of the structure remaining simple at the same time, thus a number of simplifications are taken that significantly speed up the calculation and have a little impact on results, especially on the final objective function. This model is made of shell and beam elements that represent major parts of internal and external structure. The internal structure consists of fuselage bulkheads and stringers, wing ribs and spars. Only one of the halves is created with a suitable symmetry condition. The structure of the vertical stabilizer is omitted to simplify calculations. In fact, this stabilizer is sized by non-symmetric loads that are not considered.

The whole structure is divided into regions that are defined by the same structural property like thickness for shells or cross section area for beams. These parameters can be used in structure optimization as variables. Boundaries of regions are defined by section of internal structure features.

Aircraft model is loaded by the most common loads that appear during operation. All loads that appear very rarely such as the force caused by a collision, airplane maintenance, improper assembly, lightning or fires and explosions are omitted. It is assumed that these forces are not very important at the preliminary design stage and should be considered only during the final sizing of a specific design solution. Giving the above, the model is loaded with several types of loads:

- Pressure loads resulting from air flow around the aircraft

- Inertia of structure, applied by setting mass, changing magnitude and direction of acceleration vector acting on the plane

- Inertia of components installed on the aircraft, applied by forces on bulkheads with the respective values and directions

- Thrust of motor - introduced in the stringers at the end of the fuselage.

Combined load cases are created by linear combination of the listed above types of loads in accordance with commonly used principles $[13,14]$. Generally, they are created for characteristic points that create load envelope. The definition of the envelope is extracted from aviation regulations CS-VLA [15]. Only brutal control envelope and symmetric load cases are considered. 

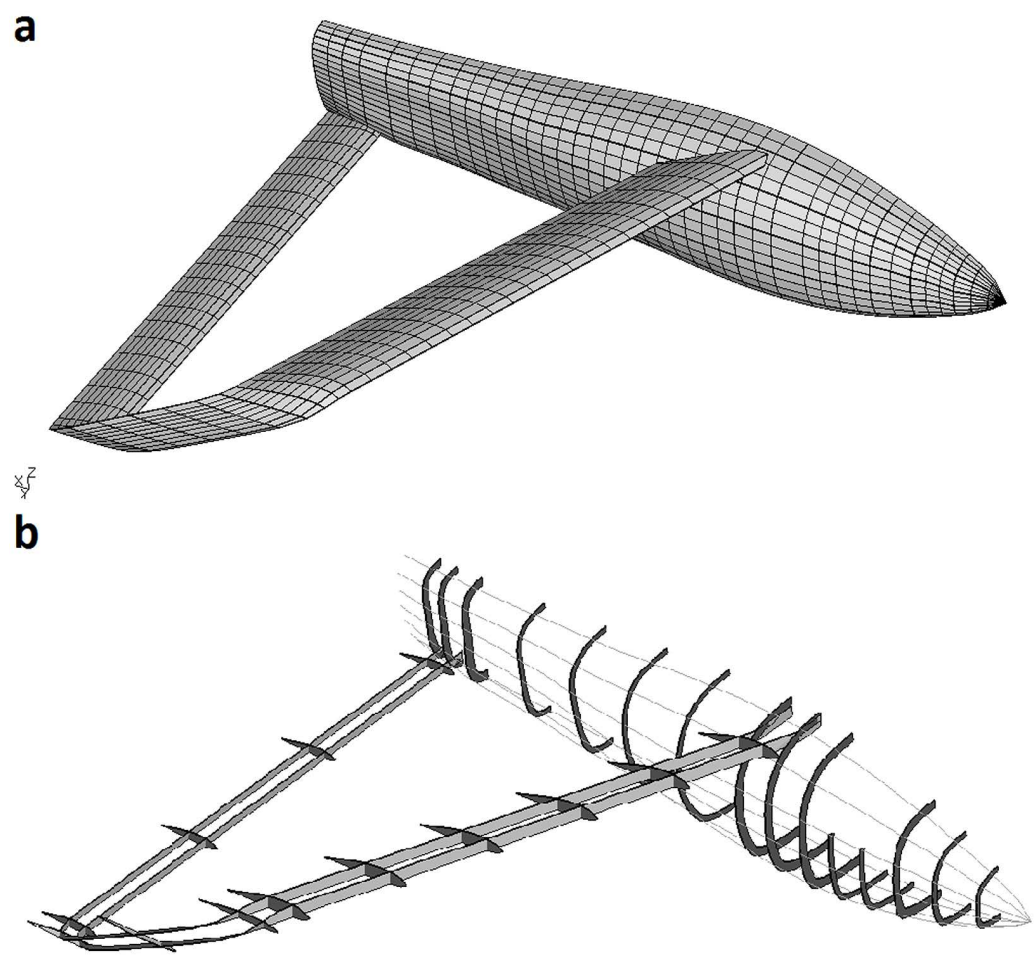

$\frac{x^{2}}{x}$

Pic. 3. FEM model, external a) and internal b) structure [Kalinowski, 2016].

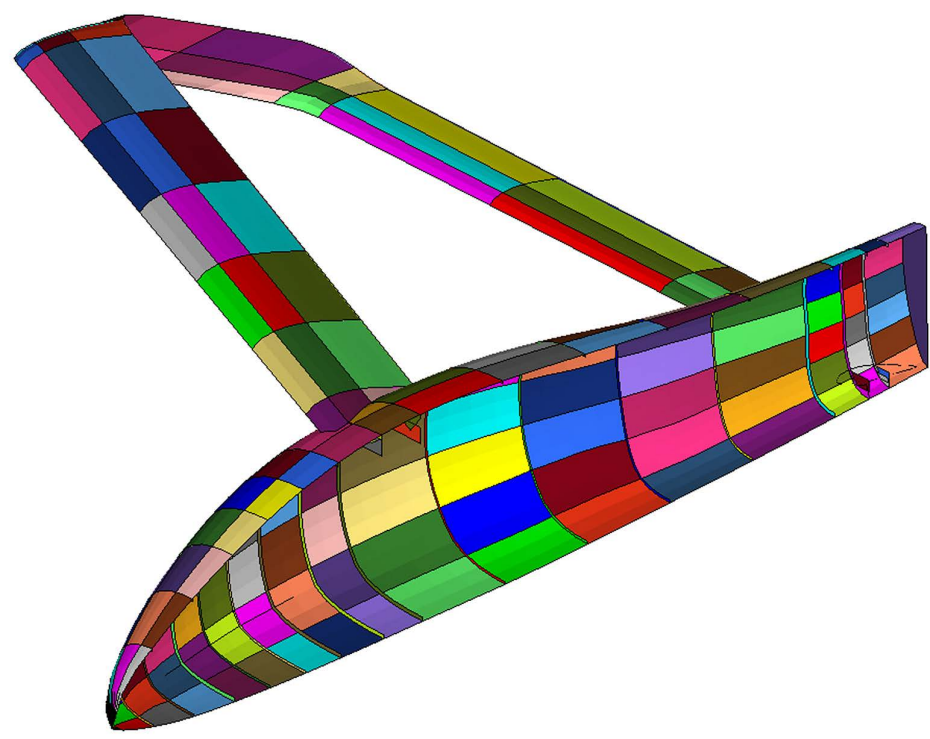

Pic. 4. Sample definition of the same structural property regions [Kalinowski, 2016]. 
The calculations were made in program Calculix [16]. For sizing of the aircraft structure linear static analyses were conducted. Structure integrity checks were based on static strength and local stability criterions. They are performed for each characteristic load envelope point. For all elements over one particular structure property only one case is selected. This critical case is characterized by the lowest strength reserve which is used for sizing the whole property region.

\subsection{Aerodynamic Model}

Aerodynamic flow around aircraft is solved by the program Panair [17] which is an implementation of the second order panel method. This program compared to software based on the Navier-Stokes quickly obtains a solution. However, it completely ignores the impact of fluid viscosity. For this reason, viscous drag estimation is performed using analytic formulas and final drag coefficient is calculated as a sum of Panair and friction coefficients.

The aerodynamic model is also a half of aircraft with defined plane of symmetry. On the aircraft surfaces the condition of the wall is applied. This enforces the tangential flow near the surface. Only on the rear of the fuselage (motor mount area) the condition of separated flow is set. Additionally, the model has defined eddies starting from sharp edges of the wings and the fuselage. In these places Kutta condition at the trailing edge is set.

Panair provides the following physical parameters used in further calculations:

- Distribution of pressure coefficient over aircraft surfaces

- Aerodynamic coefficients $C_{L}, C_{D}, C_{M}$

- Total loads acting on aircraft.

The values of coefficients $C_{L}$ and $C_{M}$ are obtained from the integration of pressures over entire surface of aircraft. The value of the $C_{D}$ is determined in the Trefftza plane.

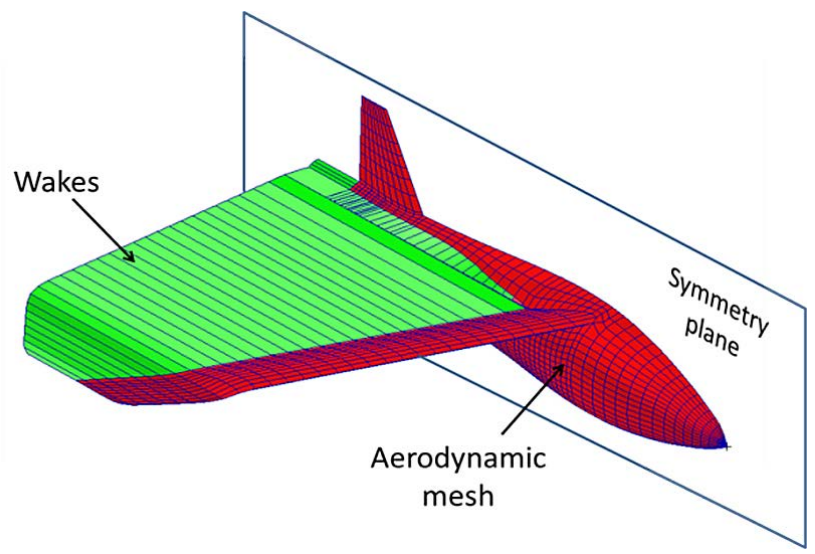

Pic. 5. Aerodynamic model of joined-wing aircraft [Kalinowski, 2016].

Correct determination of the friction drag requires a complex aerodynamic calculations based on averaged Navier-Stokes equations, which is a highly time consuming process. In addition, a wrong choice of turbulence model may cause the results differ significantly from reality. 
For these reasons, it was decided to use the analytical methods $[18,19]$, which estimate friction drag well enough in the considered speed range. It was assumed that the total friction drag acting on the aircraft is a weighted average of the resistance of individual shapes:

$C_{D 0}=\sum_{i=1}^{N} \frac{F F_{i} C_{F_{i}} S_{w e t_{i}}}{S_{\text {ref }}}$

where: $C_{F_{i}}$ - friction coefficient of shape i, $F F_{i}$ - form factor for shape i, $S_{\text {wet }_{i}}$ - sweat area of shape i, $S_{r e f}$ - reference area.

\subsection{AERODYNAMIC CHARACTERISTICS}

Determination of balance conditions of the aircraft requires the aerodynamic characteristics $F_{L}, F_{D}, M_{a}$ to be known for the flight conditions. Unfortunately, determination of characteristics in the whole needed range is time consuming and requires a lot of flow simulations. Moreover, determination of balance for characteristic envelope points requires determination of characteristics on these points separately. From an aerodynamic point of view, the balance of the aircraft is achieved by changing the angle of attack, rudder angle. It means that characteristics have two variables and need a lot of single runs to determine. This is simplified by using approximation formulas:

$F_{L}(\alpha, \delta)=0.5 \rho V^{2} S C_{L}(\alpha, \delta)=0.5 \rho V^{2} S\left(A_{1} \alpha^{2}+A_{2} \alpha+A_{3} \alpha^{2} \delta+A_{4} \alpha \delta^{2}+A_{5} \alpha \delta+A_{6} \delta+A_{7}\right)$

$F_{L}(\alpha, \delta)=0.5 \rho V^{2} S C_{L}(\alpha, \delta)=0.5 \rho V^{2} S\left(A_{1} \alpha^{2}+A_{2} \alpha+A_{3} \alpha^{2} \delta+A_{4} \alpha \delta^{2}+A_{5} \alpha \delta+A_{6} \delta+A_{7}\right)$

$M_{a}(\alpha, \delta)=0.5 \rho V^{2} S c C_{M}(\alpha, \delta)=0.5 \rho V^{2} S c\left(C_{1} \alpha^{2}+C_{2} \alpha+C_{3} \alpha^{2} \delta+C_{4} \alpha \delta^{2}+C_{5} \alpha \delta+C_{6} \delta+C_{7}\right)$

where: $\rho$ - air density, $V$ - velocity, $S$ - area, $c$ - chord.

These approximation equations are a second order polynomials with respect to both variables $\alpha$ and $\delta$. Such a simplification allows to limit the number of required runs to 7 .

\subsection{Determination of $C_{L \max }$}

Due to omitting friction phenomena, the panel method is also unable to predict flow separation and related stall. Determination of the maximum and minimum values of the coefficient of lift is necessary to create load envelope of the aircraft, which is solved by using the pressure difference method. It is an empirical rule created by Valarezo and Chin [20]. The general purpose of it is that the maximum lift appears when the absolute value of difference between peak and trailing edge pressure coefficients rise to a specific value. This value is a function of Reynolds number and Mach number. 


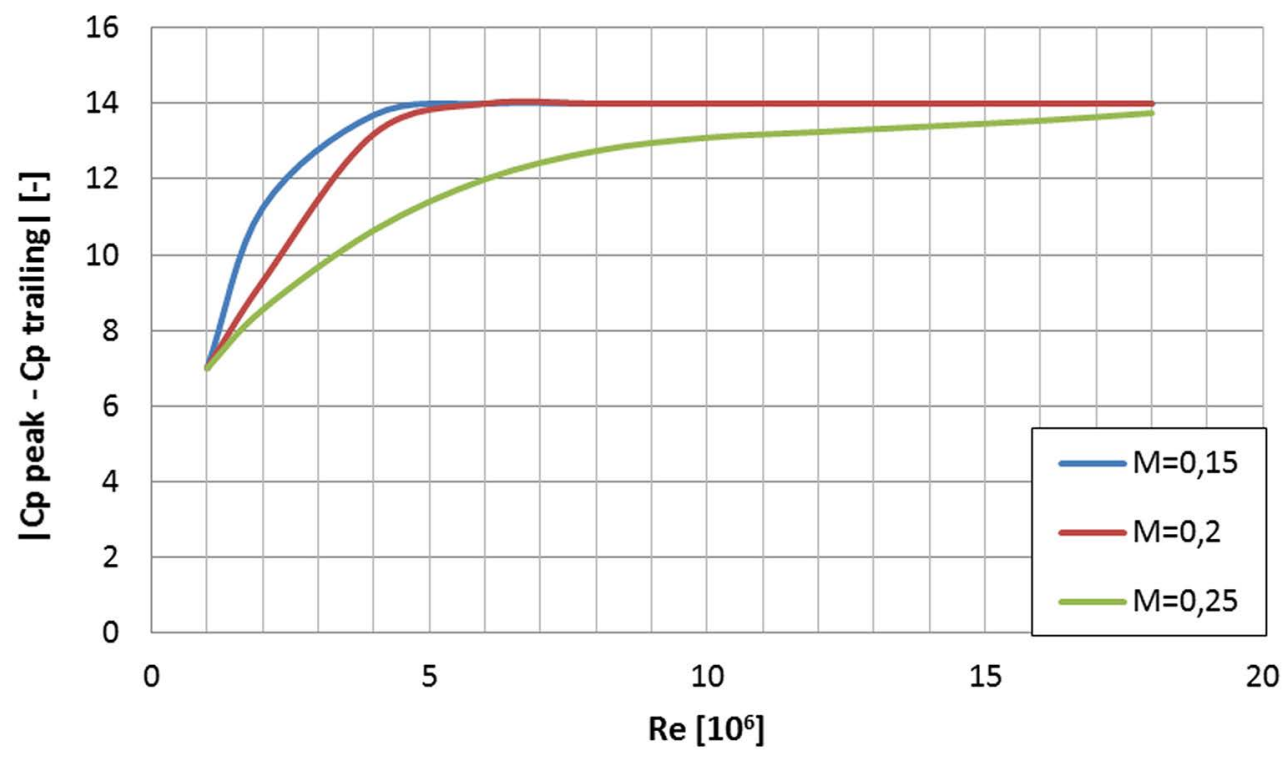

Pic. 6. Pressure difference rule [Kalinowski, 2016].

\subsection{Balancing}

Determination of the balancing conditions of the aircraft is necessary to perform flow analyses in flight conditions and to prepare pressure loads for strength calculations in steady flight maneuvers. For a symmetrical flight, balance is reduced to the situation in figure 6 . The aircraft is loaded by aerodynamic resultant loads, motor thrust and mass. In order to simplify the calculations, aerodynamic forces are determined in the center of gravity. The task is to find balance parameters $\alpha, \delta$ and $F_{c}$ that ensure a balance of forces and moments.

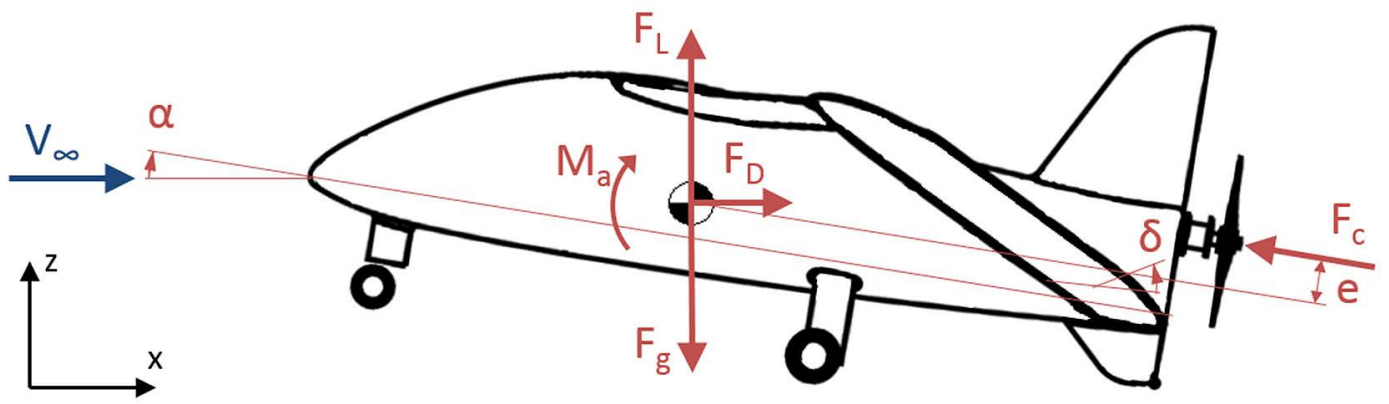

Pic. 7. Forces acting on aircraft during steady flight [Kalinowski, 2016]. 
Taking into account all the loads acting on aircraft following balance conditions can be written as:

$F_{L}(\alpha, \delta)-n F_{g}+F_{c} \sin \alpha=0$

$F_{D}(\alpha, \delta)-F_{c} \cos \alpha=0$

$M_{a}(\alpha, \delta)-F_{c} e=0$

where: $F_{c}$-motor thrust, $e$ - eccentricity of motor thrust vector, $F_{g}$ - weight of aircraft, $n$ - load factor.

Once a solution of this system of equations is known, balance parameters $\alpha, \delta, F_{c}$ can be used to perform a final flow simulation.

\section{MISSION}

Electric aircrafts are characterized by a relatively low range and endurance. For this reason, unless solar batteries are installed, electric aircrafts are dedicated to short missions, which usually have two profiles:

- Flight to specified destination - the range of aircraft is important

- Loiter to gather information - the endurance of aircraft is important.

The author decided to focus on a flight to destination mission. Aircrafts designed for such a mission are expected to have a possibly long range. For this reason, it was assumed that during the optimization of the objective function is based on the range of aircraft.

Performance of the aircraft with an electric motor differ significantly from those with conventional avgas engines. The main reasons are big differences in the characteristics of the engine and mass changing during the flight (batteries remain on board for the whole flight). Instead of this, electric motor consumes electrical energy stored in batteries. It was assumed for the purposes of the optimization that the aircraft consumes the entire electric energy during climb and flight. Descent is just a gliding.

A small capacity of batteries causes that the range of the aircraft with an electric drive is relatively small. For this reason the total range was used as an objective, including the distance traveled during ascent and descent.

$L=L_{\text {climb }}+L_{\text {cruise }}+L_{\text {desc }}$

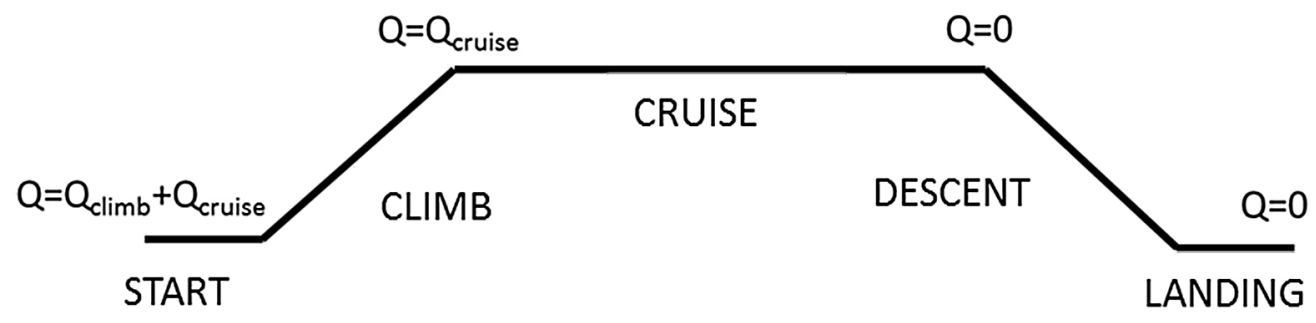

Pic. 8. Mission stages of electric aircraft [Kalinowski, 2016]. 


\section{OPTIMIZATION APPROACH}

The proposed optimization algorithm is designed for maximization of the total range of joined-wing aircraft but it can be easily modified for other objectives. The process (pic. 10) starts with generation of sets of geometric design variables using Latin hypercube method. Next, for each set of design variables (each geometry) structural optimization is performed (Pic. 9). During this stage only structural design variables are changed. After this stage is finished, a set of objective function points are created. These are next used for creating a meta-model based on radial functions.

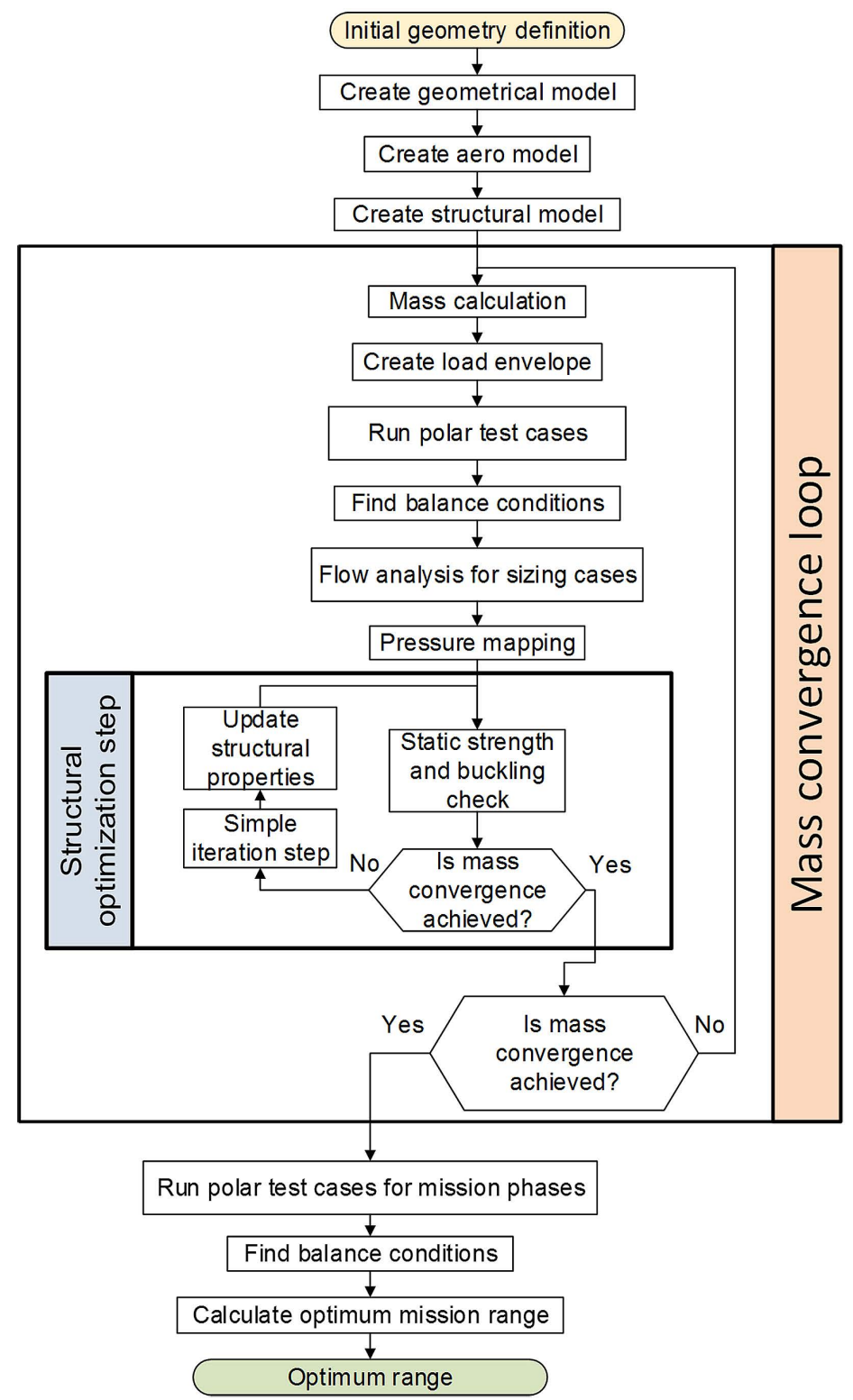

Pic. 9. Range optimization algorithm (for a specified geometry) - generation of training point [Kalinowski, 2016]. 
The final optimization is executed in a two-stage process. The first one, and at the same time the global stage, is an optimization with the use of genetic methods. A whole design variables space is explored for the best result of the objective function. Due to the simplification of the response surface method and a limited number of generation is not necessarily a global optimum. Results from the first stage are the starting point for the second local step to get closer to the maximum of the objective function. It used in the algorithm of the gradient of the family of algorithms.

Algorithm compares different solutions (aircraft geometries) using objective function that depends on design variables. The base component of this function is a total range of aircraft. The additional component is a penalty function that allows to introduce constraints on longitudinal stability margin and minimum stall speed. Two kinds of penalty function were used, with linear and quadratic dependency for constrained parameters. Objective function is defined by the following equation:

$F_{\text {objective }}(X)=L(X)-P E N A L T Y\left[\frac{d C_{M}}{d C_{L}}(X), V_{S}(X)\right]$ where: $X$ - vector of design variables, $L-$ total range of aircraft, $\frac{d C_{M}}{d C_{L}}-$ derivative of momentum
coefficient with respect to lift coefficient, $V_{S}$-stall speed.

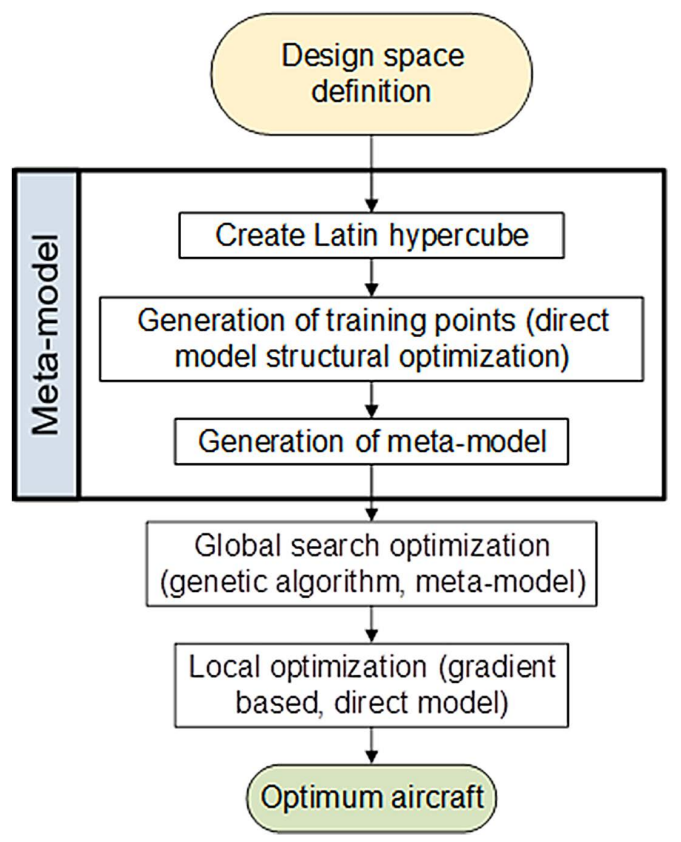

Pic. 10. Multidisciplinary optimization algorithm [Kalinowski, 2016]. 


\section{CASE STUDY}

Proposed algorithm was tested through a solution of UAV aircraft range maximization problem. It was decided to scope on joined-wing with wing span of $2.86 \mathrm{~m}$. A similar configuration of aircraft has already been built and tested in the wind tunnel in the Institute of Aviation [21] thus, there was a possibility to validate aerodynamic calculations and check what possible benefits in the aircraft range could be achieved. Moreover, the same equipment mass and its distribution as for the tested aircraft was assumed. Also electric motor of $3 \mathrm{~kW}$ of power and batteries of $9.6 \mathrm{Ah}$ capacity were the same.

The objective function $F_{\text {objective }}(X)$ was defined as a total range reduced by a penalty. Direct constraints were: the strength of the structure, the maximum value of stall speed of $16.5 \mathrm{~m} / \mathrm{s}$ and a static longitudinal stability margin higher than 0 . It were selected 232 structural design variables (thickness of wing and fuselage panels, ribs, spar walls and local cross section areas of stringers). Regarding geometry, 18 design variables were defined (skew and dihedral angles, local twist angles and local chord lengths). For all the specified variables minimum and maximum values were set. Additionally, an aircraft structure was created from carbon fiber composite, thus the change of panel thickness was discrete and constrained to one ply thickness.

The creation of a response surface meta-model was performed with an assumption of 500 test geometries. For the purpose of quality checking of meta-model additional 50 test points were generated and determination coefficient $R^{2}$ calculated. Two meta-models with two kinds of penalty functions based on polynomials were used. The difference was an order of used polynomial. Linear penalty function was characterized by a linear dependence on exceedance of constraints, whereas the second kind of penalty was a square relationship. In both functions penalty raised when the constrained values were exceeded.

Tab. 1. Comparison of optimization results, BASE - baseline configuration, LINEAR - model based on linear penalty function, SQUARE - model based on quadratic penalty function. $R^{2}$ is a determination coefficient. [Kalinowski, 2016]

\begin{tabular}{|c|c|c|c|c|}
\hline $\begin{array}{c}\text { Meta- } \\
\text { model }\end{array}$ & $\boldsymbol{R}^{2}$ & $\boldsymbol{V}_{\boldsymbol{s}}[\mathbf{m} / \mathbf{s}]$ & Range $[\mathbf{k m}]$ & $\boldsymbol{M}_{\text {tot }}[\mathbf{k g}]$ \\
\hline BASE & - & 16.8 & 56.8 & 25.6 \\
\hline LINEAR & 0.654 & 15.9 & 67.6 & 23.6 \\
\hline SQUARE & 0.662 & 16.9 & 61.4 & 23.7 \\
\hline
\end{tabular}

The results of the optimization tasks based on both meta-models are characterized by a higher range than for baseline configuration. However, solutions of both optimization tasks differ completely in wing configuration. Linear penalty based on meta-model gives a separated, poorly coupled wing system, whereas quadratic penalty based on optimization generate a strongly coupled configuration. The first of them is the best solution. A probable reason for that is the fact that the center of gravity almost has no possibility to move because the equipment positions are frozen. Optimization 

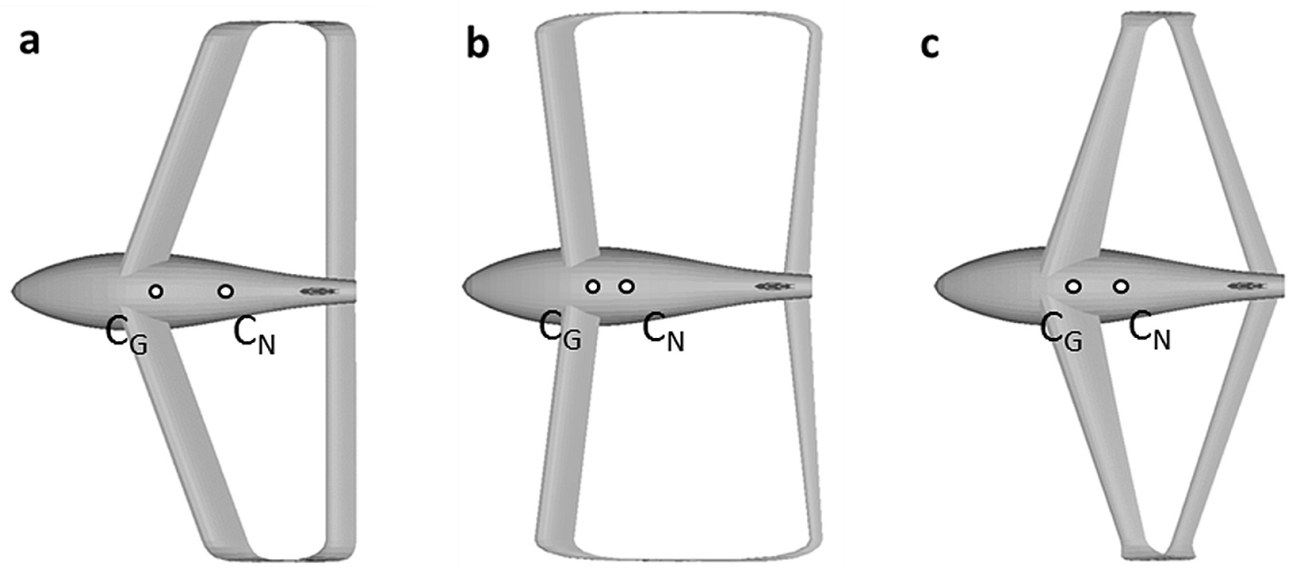

Pic. 11. Comparison of optimization results - top view, a) baseline model, b) optimization with linear penalty function (poorly coupled), c) optimization with quadratic penalty function (strongly coupled), CG - center of gravity, $\mathrm{CN}$ - neutral point [Kalinowski, 2016].

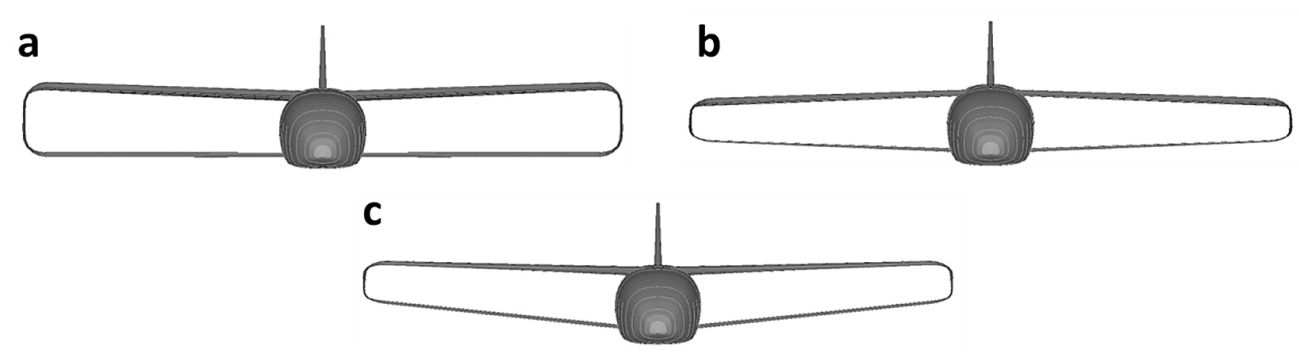

Pic. 12. Comparison of optimization results - front view, a) baseline model, b) optimization with linear penalty function (poorly coupled), c) optimization with quadratic penalty function (strongly coupled) [Kalinowski, 2016].

a

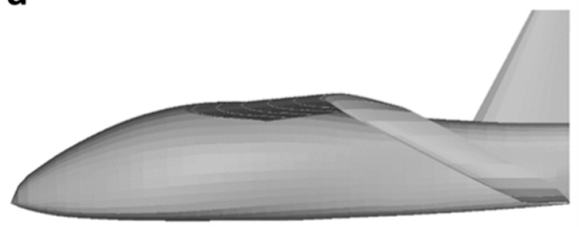

b

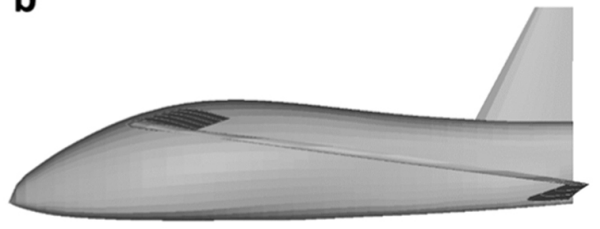

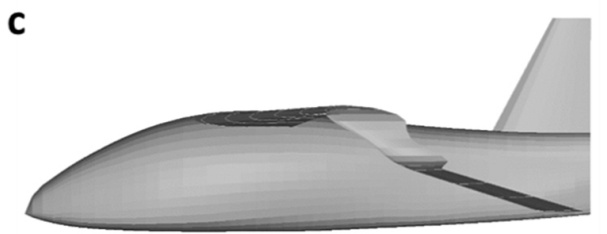

Pic. 13. Comparison of optimization results - side view, a) baseline model, b) optimization with linear penalty function (poorly coupled), c) optimization with quadratic penalty function (strongly coupled) [Kalinowski, 2016]. 
algorithm tries to put the center of gravity between wings by changing wing skew angles in such a way. This effectively decreases negative effects of trimming and reduce drag in cruise condition. On the other hand, there is no profit from using joined-wing because there is very low aerodynamic coupling.

The second solution is probably a local maximum of objective function. Quadratic penalty function is much steeper than linear constraint, thus gradient based algorithm has more problems with omitting local minimums, especially when meta-model is used. The detailed investigation shows that this configuration has a much higher margin of stability than a poorly coupled joined-wing solution (Pic. 11). This indicates the possibility of higher reduction of trimming effect for a strongly coupled configuration.

\section{CONCLUSION}

The proposed aero-structural optimization algorithm can effectively improve the range of aircraft. In comparison to the baseline configuration an improvement of $19 \%$ was achieved. However, the performed case studies show that optimization with a determined position of equipment directs the solution to a poorly coupled configuration and significantly reduce the objective function. Algorithm tries to minimize the margin of longitudinal stability to obtain the optimum configuration. In fact, the drag of aircraft configurations with a different margin of stability cannot be effectively compared because of different possibilities of its reduction by moving the center of gravity. For this reason, further work is planned to check what the optimization possibility is when the value of stability margin is enforced by moving the equipment.

\section{ACKNOWLEDGMENT}

This work was supported by The National Centre of Research and Development under grant No. PBS1/A6/14/2012.

\section{REFERENCES}

[1] Prandtl, L.: Induced drag of multiplanes, 1924, NACA TN 182

[2] Wolkovitch, J., 1986, “The Joined Wing: An Overview”, Journal of Aircraft, 23(3), pp. 161-178.

[3] Gallman, J., Smith, C., Kroo, I., 1993, “Optimization of Joined-Wing Aircraft”, Journal of Aircraft, 30(6), pp. 897-905.

[4] Gagnon, H., Zingg, D., 2015, “Aerodynamic Optimization Trade Study of a Box-Wing Aircraft Configuration", 56th AIAA/ASCE/AHS/ASC Structures, Structural Dynamics, and Materials Conference, Kissimmee.

[5] Kalinowski, M., 2011, „Koncepcja doboru struktury skrzydła samolotu w układzie połączonego skrzydła" ("Conceptual design of wing structure for joined wing aircraft”), M.S. thesis, Warsaw University of Technology.

[6] Kalinowski, M., 2015, "Structural Optimization of Box Wing Aircraft”, Archive of Mechanical Engineering, 62(1), pp. 45-60. 
[7] Kim, Y., Park, G., Kolonay, R., Blair, M., Canfield, R., 2008, "Nonlinear Response Structural Optimization of a Joined Wing Using Equivalent Loads", AIAA Journal, 46(11), pp. 2703-2712.

[8] Bindolino, G., Ghiringhelli, G., Terraneo, M., 2010, "Multilevel Structural Optimization for Preliminary Wing-Box Weight Estimation”, Journal of Aircraft, 47(2), pp. 475-489.

[9] Sivaji, R., Marisarla, S., Narayanan, V., Kaloyanova, V., Ghia, U., Ghia, K., 2003, "Aerodynamic and Structural Analyses of Joined Wings of Hale Aircraft", New Developments in Computational Fluid Dynamics: Proceedings of the Sixth International Nobeyama Workshop on the New Century of Computational Fluid Dynamics, Nobeyama.

[10] Rasmussen, C., Canfield, R., Blair, M., 2006, “Joined-Wing Sensor-Craft Configuration Design", Journal of Aircraft, 43(5), pp. 1470-1478.

[11] Cavallaro, R., 2008, “A code for Surface Modeling and Grid Generation Coupled to a Panel Method Aerodynamic Configuration Design", M.S. thesis, University of Pisa.

[12] Straathof, M., 2012, "Shape Parametrization in Aircraft Design: A Novel Method, Based on B-Splines", Ph.D. thesis, Delft University of Technology.

[13] Dacko, A., Ożóg, R., 2014, "Wing Loads Modeling for Aircraft Structural FE Analysis", Transport Przemysłowy i Maszyny Robocze, 2, pp. 108-111.

[14] Dacko, A., Dawood, A., 2015, "Strength and Buckling Analysis of a Composite Wing Structure Using MSC.PATRAN and MSC.NASTRAN", International Scientific Journal. Theoretical \&Applied Science, 28(8), pp. 14-31.

[15] Certification Specifications for Very Light Aeroplanes CS-VLA, 2009, European Aviation Safety Agency.

[16] http://www.calculix.de/.

[17] Magnus, A., Epton, M., 1980, “A Computer Program for Predicting Subsonic or Supersonic Linear Potential Flows About Arbitrary Configurations Using A Higher Order Panel Method, Vol. I. Theory Document (Version 1.0)”, NASA Contractor Report 3251.

[18] Bertin, J., Cummings, R., 2009, “Aerodynamics for engineers”, United States Air Force Academy.

[19] Cebeci, T., Bradshaw, P., 1977, "Momentum Transfer in Boundary Layers", McGraw-Hill, New York.

[20] Valarezo, W., Chin, V., 1994, "Method for the Prediction of Wing Maximum Lift", Journal of Aircraft, 31(1), pp. 103-109.

[21] Galiński, C., Hajduk, J., 2015, “Assumptions of the Joined Wing Flying Model Programme”, Prace Instytutu Lotnictwa, 238(1), pp. 7-21.

\section{AERODYNAMICZNO-STRUKTURALNA OPTYMALIZACJA SAMOLOTU W UKLADZIE POLĄCZONYCH SKRZYDEL}

\section{Streszczenie}

Układ połączonych skrzydeł ze względu na jego charakterystykę energetyczną jest odpowiednią konfiguracją dla samolotów z napędem elektrycznym pod warunkiem, że został on zaprojektowany 
prawidłowo. Samolot taki jednak ze względu na charakterystyczne dla niego zjawiska (np. statyczna niewyznaczalność struktury, aerodynamiczna interferencja płatów nośnych) wymaga bardziej złożonych metod obliczeniowych by zamodelować jego zachowanie niż w przypadku klasycznych konfiguracji samolotu. Z tych powodów zaproponowany został proces optymalizacji aerodynamiczno-strukturalnej samolotu w układzie połączonych skrzydeł, odpowiedni dla projektowania wstępnego. Proces ten to modułowy algorytm globalnego przeszukiwania składający się z generatora geometrii, programów obliczeń strukturalnych metodą MES i obliczeń aerodynamicznych metodą panelową. Za funkcję celu przyjęto zasięg samolotu. Algorytm ten został z powodzeniem przetestowany na przypadku samolotu bezzałogowego. Uzyskano 19\% wzrostu całkowitego zasięgu w stosunku do konfiguracji podstawowej. Czas wykonywania tego algorytmu o charakterze globalnym jest zbliżony do czasów charakterystycznych dla optymalizacji algorytmami lokalnymi Pozwala to na zredukowanie czasu i kosztu projektowania wstępnego samolotu w układzie połączonych skrzydeł.

Słowa kluczowe: układ połączonych skrzydeł, optymalizacja multidyscyplinarna, projektowanie wstępne. 